\title{
Determining Job Performance vis-à-vis Feedback Orientation and Feedback Environment: A Study Among Academicians in Malaysia
}

Noor Azura Dahalan, Muhamad Khalil Omar, Dayang Nailul Munna Abg Abdullah, Ridhawati Zakaria, Muna Wadhiha Mohd Fauzi

To Link this Article: http://dx.doi.org/10.6007/IJARBSS/v11-i6/10211

DOI:10.6007/IJARBSS/v11-i6/10211

Received: 04 April 2021, Revised: 06 May 2021, Accepted: 24 May 2021

Published Online: 13 June 2021

In-Text Citation: (Dahalan et al., 2021)

To Cite this Article: Dahalan, N. A., Omar, M. K., Abdullah, D. N. M. A., Zakaria, R., \& Fauzi, M. W. M. (2021). Determining Job Performance vis-à-vis Feedback Orientation and Feedback Environment: A Study Among Academicians in Malaysia. International Journal of Academic Research in Business and Social Sciences, 11(6), 804-817.

Copyright: (c) 2021 The Author(s)

Published by Human Resource Management Academic Research Society (www.hrmars.com) This article is published under the Creative Commons Attribution (CC BY 4.0) license. Anyone may reproduce, distribute, translate and create derivative works of this article (for both commercial and non-commercial purposes), subject to full attribution to the original publication and authors. The full terms of this license may be seen at: http://creativecommons.org/licences/by/4.0/legalcode

Vol. 11, No. 6, 2021, Pg. 804- 817

Full Terms \& Conditions of access and use can be found at http://hrmars.com/index.php/pages/detail/publication-ethics 


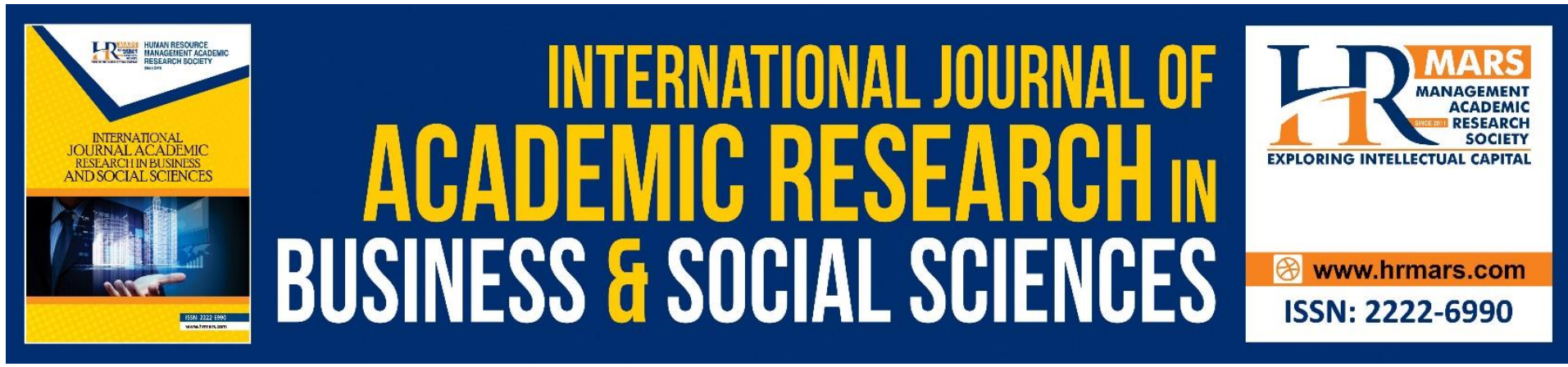

\title{
Determining Job Performance vis-à-vis Feedback Orientation and Feedback Environment: A Study Among Academicians in Malaysia
}

\author{
Noor Azura Dahalan, Muhamad Khalil Omar, Dayang Nailul \\ Munna Abg Abdullah, Ridhawati Zakaria, Muna Wadhiha Mohd \\ Fauzi \\ Universiti Teknologi MARA, Centre for Management and Administrative Studies, Faculty of \\ Business and Management, 42300. Puncak Alam. Malaysia
}

\begin{abstract}
This paper describes whether performance feedback can greatly affect job performance. Hence, this study intends to determine the effects of feedback environment (i.e. its dimensions of source credibility, feedback quality, feedback delivery, favorable feedback, unfavorable feedback, source availability and promotes feedback seeking) as well as feedback orientation (i.e. its dimensions of utility, accountability, social awareness, and feedback selfefficacy) towards job performance. Feedback is defined as information about performance that allows a performer to change his or her behavior. Whilst performance feedback is often described as information that is presented to a performer that enables a change in his or her future performance. Feedback environment is characterized by the availability of valid and valuable feedback that is provided in a constructive way and on a regular basis). On the other hand, feedback orientation is employee's willingness and ability to receive, process, and use feedback. Using purposive samples of 96 academician of a public university in Malaysia, the findings of this study established that, feedback orientation of feedback self-efficacy and feedback environment of favorable feedback have significant effects towards job performance. The significance of this study can contribute numerous advantages to many organisations and the corporate sectors in forming their business strategy specially to cope with industry revolution 4.0 in Malaysia. This study also provides the human resources management team further insights on ways to improve job performance and this will allow organisations to gain profitable entity. Apart from that, this study will provide some directions for future researchers in concerning of feedback and job performance studies.
\end{abstract}

Keywords: Job Performance, Feedback Orientation, Feedback Environment, Academician

\section{Introduction}

Feedback is an effective method for increasing employee performance in a wide range of settings, although questions remain regarding the most effective characteristics of feedback. Even though there is little research on the sequence of feedback messages, recommendations advocating a particular sequence are often made in practice (Henley, 2014). Feedback is 
frequently delivered using improper approaches that lead to unproductive outcomes (Baker et al., 2013). Therefore, even though feedback can be a valuable method to improve job performance, it nevertheless continues to be one of the most underused and misused tools by managers and supervisors in organizations today (Romero, 2012). Depending on individual and contextual factors (Mulder \& Ellinger, 2013), feedback can help or hinder a person's motivation and performance. A poor understanding of such factors has led to a workplace reality where both informal and formal feedback are often considered to be a negative experience (Baker et al., 2013). In organizational behavior management, performance feedback is often described as information that is presented to an employee that enables changes in his or her future performance. Performance feedback is frequently used in combination with other procedures in applied settings (Guadalupe, 2018). Studies showed managers rank feedback as one of their most difficult duties, as relationship building was critical to the goals of the organization (Zenger, 2014). Some researchers have studied the probable sources of feedback; however, few researches have been done on the issue of feedback relative to the effectiveness of managers (Zenger, 2014).

\section{Literature Review}

According to Wolf (2012), feedback is usually given to employees by superior or supervisor and represents an estimate of the employees' job performance and efforts in and for the organization. It should be noted that feedback is usually displayed and discussed among two or more people. Employees who receive more feedback from their supervisor will be more likely to know the standards of good performance, to believe that performing well will lead to desired rewards and be more likely to use feedback to improve their own performance (Steelman et al., 2004).

The value and importance of feedback to direct and motivate behavior is well known. Meaningful feedback can be used to guide, motivate and reinforce effective behaviors and put a halt to ineffective behaviors. Negative feedback, indicating one's job performance is not meeting expectations, is clearly of developmental value to an individual and of strategic value to organizations. Supervisors have a primary responsibility for making and communicating organizational decisions to their subordinates. Thus, supervisors exert greater influence and power, especially in the arena of dispensing organizational rewards and punishments (Steelman et al., 2004). Employees must be satisfied enough with their job and try to create good relationship with the supervisor by listening and taking actions on feedbacks given to them on the job that had been done in order to achieve better job performance. It is known that supervisors might collect several specific behaviors to support feedback processes in the organization, which might lead to an enhanced manager and subordinate relationship and satisfaction (Anseel et al., 2007). Anseel et al (2007) also found that perceptions of feedback accuracy (i.e. acceptance) were positively related to employees' intentions to use feedback in improving job performance.

Other than that, only $50 \%$ of those who have received feedbacks were capable of displaying job-improvement following feedback session with the supervisor. If the person is not able to accept comments and critique, he or she is bound to suffer from setbacks, feeling of helplessness, and bitter disappointment that will interfere with his or her work in the future (Wolf, 2012). Feedback has been heavily researched in the context of work and learning by human resource specialists, industrial and organizational psychologists, business 
management experts, and organizational behavior researchers (Van der Rijt et al., 2012; Mulder \& Ellinger, 2013). The benefits of well-designed feedback approaches are widespread (Baker et al., 2013). Rolison et al (2012) suggested that information from developmental feedback is useful and motivating regardless of whether it is positive or negative. Positive and negative feedback are both desirable above and beyond as there are part of a learning episode feedback (Rolison et al., 2012).

Feedback environments may also enable feedback seeking that is motivated by other concerns, such as image enhancement. As Dahling and O'Malley (2011) recently summarized, supportive feedback environment perspective is associated with a variety of desirable outcome for employees and organization, such as higher affective commitment and morale. The relationship between feedback mechanisms and performance improvement is not just a simple, positive, variables phenomenon. While the primary purpose of performance feedback (e.g., constructive criticism) is to reshape behavior to align with performance expectations (Kaymaz,2011), confounding issues such as personality, trait based self-efficacy, emotional stability, goal orientation, and affective disposition (Feys et al., 2011), intrinsic motivation levels (Guo et al., 2014), supervisor-subordinate relationship (Kaymaz, 2011), and age or generational differences (Stewart \& Bernhardt, 2010), moderate the impact of feedback on the feedback recipient and, consequently, on performance.

Creating and delivering a specific message based on an observed or identified performance can impact the delivery of effective feedback. Although there are varying views that stress the impact of feedback on performance, little stress is given to the effectiveness of the delivery of feedback on performance (Ellison, 2015). Based on the reviewed literature, the following hypotheses were developed:

$\mathrm{H}_{1}$ : There is a relationship between utility and job performance among academicians.

$\mathrm{H}_{2}$ : There is a relationship between accountability and towards job performance among academicians.

$\mathrm{H}_{3}$ : There is a relationship between social awareness and job performance among academicians.

$\mathrm{H}_{4}$ : There is a relationship between feedback self-efficacy and job performance among academicians.

$\mathrm{H}_{5}$ : There is a relationship between source credibility and job performance among academicians.

$\mathrm{H}_{6}$ : There is a relationship between feedback quality and job performance among academicians.

$\mathrm{H}_{7}$ : There is a relationship between feedback delivery and job performance among academicians.

$\mathrm{H}_{8}$ : There is a relationship between favorable feedback and job performance among academicians.

$\mathrm{H}_{9}$ : There is a relationship between unfavorable feedback and job performance among academicians.

$\mathrm{H}_{10}$ : There is a relationship between source availability and job performance among academicians.

$\mathrm{H}_{11}$ : There is a relationship between promotes feedback seeking and job performance among academicians. 
Based on the literatures discussed earlier are illustrated in a research framework as per Figure

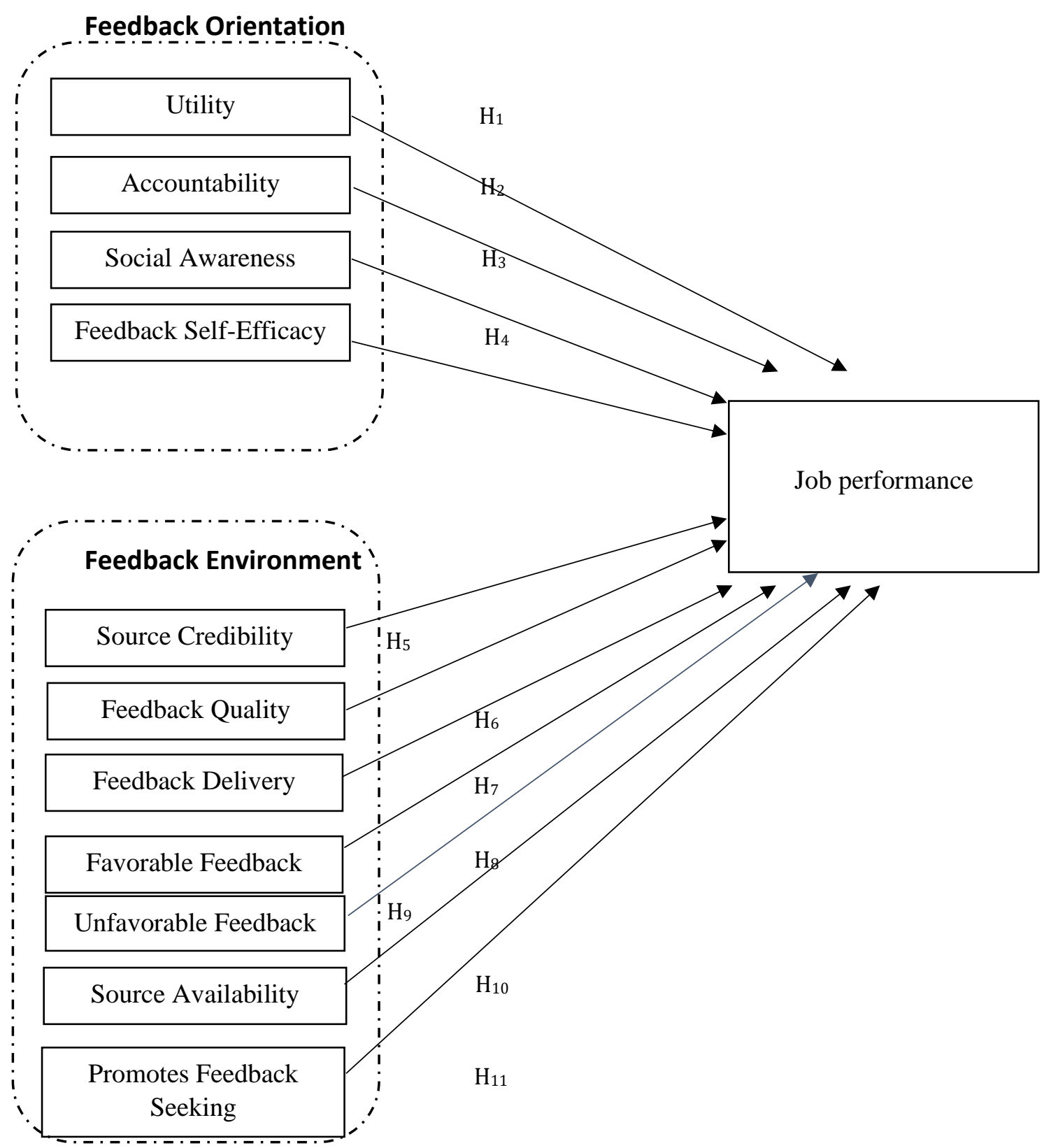

Figure 1. Research Framework

\section{Research Methodology}

Quantitative method was used in conducting this research to identify the relationship between feedback and job performance among academician in Selangor. 190 academicians from selected universities made up the population sample for this study where 96 academicians were then selected as the chosen sample. The non-probability sampling design of purposive sampling technique was used for this study. Purposive sampling is confined to specific types of people who can provide the desired information, either because they are the only ones who have it, or match the criteria set by the researchers. In this research, the researchers used structured questionnaire where all respondents had received the same set of questionnaires. Sample of measurements used in this study are shown in Table 1. 
Table 1: Adopted Measurements

\begin{tabular}{|c|c|c|}
\hline Variables & Items & Source \\
\hline \multicolumn{2}{|c|}{ Feedback Orientation } & \multirow{9}{*}{$\begin{array}{l}\text { Linderbaum and } \\
\text { Levy (2010) }\end{array}$} \\
\hline \multirow[t]{2}{*}{ Utility } & Feedback contributes to my success at work. & \\
\hline & $\begin{array}{l}\text { To develop my skills at work, I rely on } \\
\text { feedback. }\end{array}$ & \\
\hline \multirow[t]{2}{*}{ Accountability } & $\begin{array}{l}\text { It is my responsibility to apply feedback to } \\
\text { improve my performance. }\end{array}$ & \\
\hline & $\begin{array}{l}\text { I hold myself accountable to respond to } \\
\text { feedback appropriately. }\end{array}$ & \\
\hline \multirow[t]{2}{*}{ Social Awareness } & $\begin{array}{l}\text { I try to be aware of what other people think } \\
\text { of me. }\end{array}$ & \\
\hline & $\begin{array}{l}\text { Using feedback, I am more aware of what } \\
\text { people think of me. }\end{array}$ & \\
\hline \multirow[t]{2}{*}{ Self-Efficacy } & feel self-assured when dealing with feedback. & \\
\hline & $\begin{array}{l}\text { Compared to others, I am more competent at } \\
\text { handling feedback. }\end{array}$ & \\
\hline \multicolumn{2}{|c|}{ Feedback Environment } & Steelman et al. \\
\hline \multirow[t]{2}{*}{ Feedback Quality } & $\begin{array}{l}\text { My supervisor gives me useful feedback about } \\
\text { my job performance. }\end{array}$ & $(2004)$ \\
\hline & $\begin{array}{l}\text { The performance feedback I receive from my } \\
\text { supervisor is helpful. }\end{array}$ & \\
\hline \multirow[t]{2}{*}{ Source Credibility } & $\begin{array}{l}\text { My supervisor is generally familiar with my job } \\
\text { performance. }\end{array}$ & \\
\hline & $\begin{array}{l}\text { In general, I respect my supervisor's opinions } \\
\text { about my job performance }\end{array}$ & \\
\hline \multirow[t]{2}{*}{ Feedback delivery } & $\begin{array}{l}\text { My supervisor is supportive when giving me } \\
\text { feedback about my job performance. }\end{array}$ & \\
\hline & $\begin{array}{l}\text { When my supervisor gives me performance } \\
\text { feedback, he or she is considerate of my } \\
\text { feelings. }\end{array}$ & \\
\hline \multirow[t]{2}{*}{$\begin{array}{l}\text { Favorable } \\
\text { feedback }\end{array}$} & $\begin{array}{l}\text { When I do a good job at work, my supervisor } \\
\text { praises my performance. }\end{array}$ & \\
\hline & I seldom receive praise from my supervisor. & \\
\hline \multirow[t]{2}{*}{$\begin{array}{l}\text { Unfavorable } \\
\text { feedback }\end{array}$} & $\begin{array}{l}\text { My supervisors will inform me when my job } \\
\text { performance falls below expectations, }\end{array}$ & \\
\hline & $\begin{array}{l}\text { My supervisors will inform me when I make a } \\
\text { mistake at work }\end{array}$ & \\
\hline \multirow[t]{2}{*}{ Source availability } & $\begin{array}{l}\text { My supervisor is usually available when I want } \\
\text { performance feedback. }\end{array}$ & \\
\hline & $\begin{array}{l}\text { My supervisor is too busy to give me } \\
\text { performance feedback. }\end{array}$ & \\
\hline $\begin{array}{l}\text { Promote } \\
\text { feedback seeking }\end{array}$ & $\begin{array}{l}\text { My supervisor is often annoyed when I } \\
\text { directly ask for performance feedback. }\end{array}$ & \\
\hline
\end{tabular}




\begin{tabular}{|l|l|c|}
\hline & $\begin{array}{l}\text { When I ask for performance feedback, my } \\
\text { supervisor generally does not give me the } \\
\text { information right away }\end{array}$ \\
\hline $\begin{array}{l}\text { Job Performance } \\
\text { I express an underlying concern for doing things better, for } \\
\text { improving situations }\end{array}$ & $\begin{array}{c}\text { Steelman et al. } \\
\text { (2004) }\end{array}$ \\
\cline { 1 - 2 } $\begin{array}{l}\text { I exhibit a willingness to go beyond what the job requires and act } \\
\text { before being asked. }\end{array}$ & \\
\cline { 1 - 2 } $\begin{array}{l}\text { I exhibit an ability to see the whole, parts and relations and use this } \\
\text { to set priorities, plan, anticipate and evaluate }\end{array}$ & \\
\hline I always get things done on time. & \\
\hline
\end{tabular}

Statistical Package for the Social Sciences or SPSS Version 25 was the software used in this study. Descriptive (frequency analysis) study is undertaken to describe the characteristics of employees (gender, education, marital status, etc.). Reliability analysis was used to measure the stability and consistency of the questionnaire. The reliability result will help to access the goodness of a measure. Pearson correlation coefficient and regression analysis were used to study the existence of relationships and impacts between variables. Regression analysis were used as to measure the most dominant factors variables influence dependent variables.

\section{Results}

The respondents of this study consist of 96 academicians of a public university. They were mainly females (69.5\%), married (66.7\%), possess master's degree (52.4\%), and earn monthly gross income between RM2001 and RM4000 (58\%). The results on Table 2 show that Cronbach's Alpha values for five variables used in the questionnaire are greater than 0.80 ( $\alpha$ $>0.80)$ whilst the remaining six variables are greater than $0.60(\alpha>0.60)$. This indicates that the questionnaire had fulfilled the minimum internal consistency of reliability. Table 2 also shows that the levels of all independent variables in this study are moderately and highly reliable. 
Table 2: Descriptive and reliability analysis for all variables.

\begin{tabular}{|c|c|c|c|}
\hline Variables & Mean & $\begin{array}{l}\text { Standard } \\
\text { Deviation }\end{array}$ & $\begin{array}{l}\text { Cronbach's } \\
\text { Alpha }\end{array}$ \\
\hline
\end{tabular}

\begin{tabular}{lccc}
\hline Feedback orientation & & & \\
1) Utility & 4.07 & 0.525 & 0.786 \\
2) Accountability & 3.98 & 0.925 & 0.618 \\
3) Social awareness & 3.85 & 0.445 & 0.722 \\
4) Feedback self-efficacy & 3.65 & 0.542 & 0.868 \\
$\begin{array}{l}\text { Feedback environment } \\
\text { 5) Source credibility }\end{array}$ & 3.76 & 0.637 & 0.928 \\
6) Feedback quality & 3.86 & 0.596 & 0.939 \\
7) Feedback delivery & 3.39 & 0.541 & 0.645 \\
8) Favorable feedback & 3.46 & 0.529 & 0.626 \\
9) Unfavorable feedback & 3.74 & 0.648 & 0.894 \\
10) Source availability & 3.14 & 0.566 & 0.625 \\
11) Promote feedback seeking & 3.11 & 0.515 & 0.897 \\
Job performance & & & \\
\end{tabular}

Reliability Analysis: Based on Table 2, the Cronbach's alpha for source credibility and feedback quality are the highest with the reading of 0.928 and 0.939 respectively, in which they were measured by five items each and were considered highly reliable. The Cronbach's alpha for the feedback self-efficacy (0.868), unfavorable feedback (0.894) and promote feedback seeking (0.897) are also considered high in reliability. In addition, for utility (0.786), accountability (0.618), social awareness (0.7222), feedback delivery (0.645), favorable feedback (0.626) and source availability (0.625) are considered moderate in reliability. Finally, the Cronbach's alpha for job performance is 0.811 which is considered reliable. According to Sekaran and Bougie (2013), the value of Cronbach's alpha that is below 0.6 is considered poor and the value that is more than 0.6 is considered reliable.

Correlation Analysis: Based on Table 3, the finding of the correlation analysis is at the value of .500 which is considered an acceptable correlation (Salkind, 2000). The highest correlation is obtained between favorable feedback and job performance with the value of .437. This value shows that there is a moderate relationship between favorable feedback and job performance. Other than that, this variable has a significant positive correlation between favorable feedback and job performance with $p=.000$. This is then, followed by utility $(r=.332$, $p=.000)$, social awareness $(r=.372, p=.000)$, self-efficacy $(r=.388, p=.000)$ in which all indicates weak relationships with job performance. It also shows the significant positive correlation between these three variables with job

performance with the reading of $p=.000$. Other variables show no relationship with job performance where the value of correlation is too weak with the range from $r=.098$ to .243 and the $p$-values are not significant. These variables demonstrate no association with job performance $(p=.017-.341)$. 
Table 3: Pearson Correlation analysis for all variables

\begin{tabular}{|c|c|c|c|c|c|c|c|c|c|c|c|c|}
\hline & $\begin{array}{c}\text { Ut } \\
\text { ilit } \\
y\end{array}$ & $\begin{array}{c}\text { Accou } \\
\text { ntabili } \\
\text { ty }\end{array}$ & $\begin{array}{l}\text { Soci } \\
\text { al } \\
\text { awa } \\
\text { rene } \\
\text { ss }\end{array}$ & $\begin{array}{c}\text { Fee } \\
\text { dba } \\
\text { ck } \\
\text { self } \\
- \\
\text { effi } \\
\text { cac } \\
\text { y }\end{array}$ & $\begin{array}{l}\text { Sou } \\
\text { rce } \\
\text { cred } \\
\text { ibili } \\
\text { ty }\end{array}$ & $\begin{array}{c}\text { Fee } \\
\text { dba } \\
\text { ck } \\
\text { qua } \\
\text { lity }\end{array}$ & $\begin{array}{c}\text { Fee } \\
\text { dba } \\
\text { ck } \\
\text { deli } \\
\text { ver } \\
\text { y }\end{array}$ & $\begin{array}{c}\text { Fav } \\
\text { ora } \\
\text { ble } \\
\text { fee } \\
\text { dba } \\
\text { ck }\end{array}$ & $\begin{array}{c}\text { Unfa } \\
\text { vora } \\
\text { ble } \\
\text { feed } \\
\text { back }\end{array}$ & $\begin{array}{l}\text { Sour } \\
\text { ce } \\
\text { avail } \\
\text { abili } \\
\text { ty }\end{array}$ & $\begin{array}{c}\text { Pro } \\
\text { mo } \\
\text { te } \\
\text { fee } \\
\text { dba } \\
\text { ck } \\
\text { see } \\
\text { kin } \\
\text { g }\end{array}$ & $\begin{array}{c}\text { Job } \\
\text { perfo } \\
\text { rman } \\
\text { ce }\end{array}$ \\
\hline $\begin{array}{c}\text { Accou } \\
\text { ntabili } \\
\text { ty }\end{array}$ & $\begin{array}{c}1 . \\
00 \\
.2 \\
51 \\
*\end{array}$ & 1.00 & & & & & & & & & & \\
\hline $\begin{array}{c}\text { Social } \\
\text { aware } \\
\text { ness }\end{array}$ & $\begin{array}{l}.5 \\
05 \\
* *\end{array}$ & .154 & 1.00 & & & & & & & & & \\
\hline $\begin{array}{c}\text { Feedb } \\
\text { ack } \\
\text { self- } \\
\text { effica } \\
\text { cy }\end{array}$ & $\begin{array}{l}.4 \\
34 \\
* *\end{array}$ & $.228^{*}$ & $\begin{array}{c}.399 \\
* *\end{array}$ & $\begin{array}{c}1.0 \\
0\end{array}$ & & & & & & & & \\
\hline $\begin{array}{l}\text { Sourc } \\
\text { e } \\
\text { credib } \\
\text { ility }\end{array}$ & $\begin{array}{c}.4 \\
15 \\
* *\end{array}$ & .024 & $\begin{array}{c}.276 \\
* *\end{array}$ & $\begin{array}{c}.40 \\
5 * *\end{array}$ & 1.00 & & & & & & & \\
\hline $\begin{array}{c}\text { Feedb } \\
\text { ack } \\
\text { qualit }\end{array}$ & $\begin{array}{l}.4 \\
90 \\
* *\end{array}$ & .133 & $\begin{array}{c}.261 \\
*\end{array}$ & $\begin{array}{l}.52 \\
3 * *\end{array}$ & $\begin{array}{c}.742 \\
* *\end{array}$ & $\begin{array}{c}1.0 \\
0\end{array}$ & & & & & & \\
\hline $\begin{array}{c}y \\
\text { Feedb } \\
\text { ack } \\
\text { delive } \\
\text { ry }\end{array}$ & $\begin{array}{c}.2 \\
14 \\
*\end{array}$ & -.008 & $\begin{array}{c}.227 \\
*\end{array}$ & $\begin{array}{l}.25 \\
7^{*}\end{array}$ & $\begin{array}{c}.437 \\
* *\end{array}$ & $\begin{array}{l}.56 \\
0 * *\end{array}$ & $\begin{array}{c}1.0 \\
0\end{array}$ & & & & & \\
\hline $\begin{array}{c}\text { Favor } \\
\text { able } \\
\text { feedb } \\
\text { ack }\end{array}$ & $\begin{array}{l}.2 \\
80 \\
* *\end{array}$ & .140 & $\begin{array}{c}.403 \\
* *\end{array}$ & $\begin{array}{c}.36 \\
4 * *\end{array}$ & $\begin{array}{c}.481 \\
* *\end{array}$ & $\begin{array}{c}.46 \\
3 * *\end{array}$ & $\begin{array}{c}.62 \\
4 * *\end{array}$ & 1.00 & & & & \\
\hline $\begin{array}{l}\text { Unfav } \\
\text { orabl } \\
\text { e } \\
\text { feedb } \\
\text { ack }\end{array}$ & $\begin{array}{l}.3 \\
12 \\
* *\end{array}$ & -.081 & $\begin{array}{c}.342 \\
* *\end{array}$ & $\begin{array}{l}.29 \\
4^{* *}\end{array}$ & $\begin{array}{c}.591 \\
* *\end{array}$ & $\begin{array}{c}.57 \\
5 * *\end{array}$ & $\begin{array}{c}.39 \\
4^{* *}\end{array}$ & $\begin{array}{c}.456 \\
* *\end{array}$ & 1.00 & & & \\
\hline
\end{tabular}




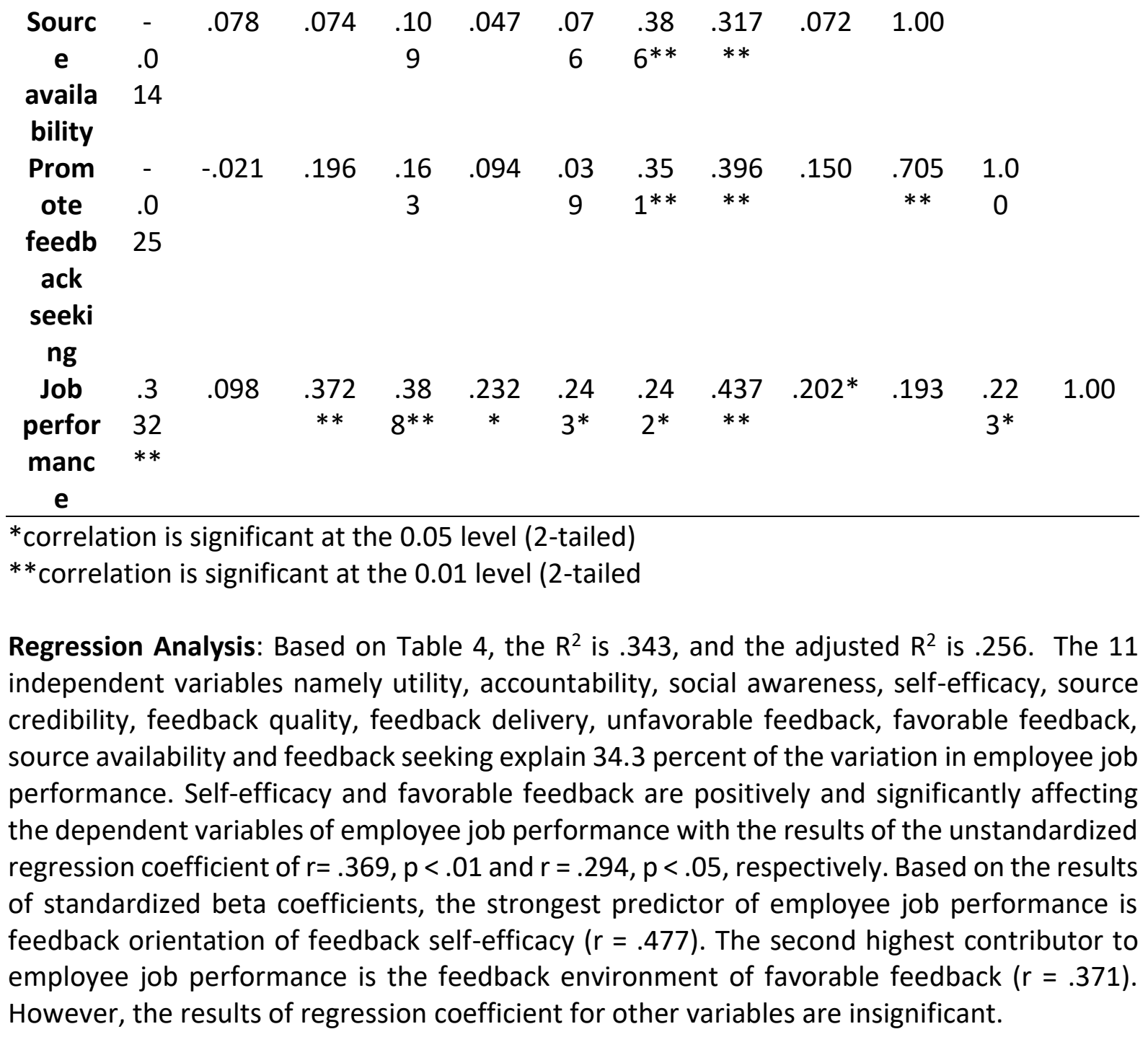

Regression Analysis: Based on Table 4 , the $R^{2}$ is .343, and the adjusted $R^{2}$ is .256 . The 11 independent variables namely utility, accountability, social awareness, self-efficacy, source credibility, feedback quality, feedback delivery, unfavorable feedback, favorable feedback, source availability and feedback seeking explain 34.3 percent of the variation in employee job performance. Self-efficacy and favorable feedback are positively and significantly affecting the dependent variables of employee job performance with the results of the unstandardized regression coefficient of $r=.369, p<.01$ and $r=.294, p<.05$, respectively. Based on the results of standardized beta coefficients, the strongest predictor of employee job performance is feedback orientation of feedback self-efficacy $(r=.477)$. The second highest contributor to employee job performance is the feedback environment of favorable feedback $(r=.371)$. However, the results of regression coefficient for other variables are insignificant. 
Table 4: Regression Analysis

\begin{tabular}{|c|c|c|c|c|c|}
\hline \multicolumn{6}{|c|}{ Dependent Variable: Job Performance } \\
\hline \multicolumn{2}{|c|}{ Independent Variables } & $\begin{array}{l}\text { Unstandardized } \\
\text { Coefficient }\end{array}$ & $\begin{array}{l}\text { Standardized } \\
\text { Coefficient }\end{array}$ & $\mathbf{t}$ & p-value \\
\hline \multicolumn{6}{|c|}{ Feedback orientation } \\
\hline \multicolumn{2}{|c|}{ 1. Utility } & .126 & .159 & 1.294 & .199 \\
\hline \multicolumn{2}{|c|}{ 2. Accountability } & -.110 & -.120 & -.889 & .376 \\
\hline \multicolumn{2}{|c|}{ 3. Social awareness } & -.130 & -.137 & -.406 & .686 \\
\hline \multicolumn{2}{|c|}{ 4. Feedback self-efficacy } & .369 & .477 & 2.490 & .015 \\
\hline \multicolumn{6}{|c|}{ Feedback environment } \\
\hline \multicolumn{2}{|c|}{ 5. Source credibility } & .037 & .056 & .377 & .707 \\
\hline \multicolumn{2}{|c|}{ 6. Feedback quality } & -.128 & -.181 & -1.117 & .267 \\
\hline \multicolumn{2}{|c|}{ 7. Feedback delivery } & -.009 & -0.14 & -.115 & .909 \\
\hline \multicolumn{2}{|c|}{ 8. Favorable feedback } & .294 & .371 & 3.082 & .003 \\
\hline \multicolumn{2}{|c|}{ 9. Unfavorable feedback } & -.046 & -0.71 & -.571 & .569 \\
\hline \multicolumn{2}{|c|}{ 10. Source availability } & .360 & .373 & 1.121 & .266 \\
\hline \multicolumn{2}{|c|}{$\begin{array}{l}\text { 11. Promote feedback } \\
\text { seeking }\end{array}$} & -.179 & -.252 & -1.336 & .185 \\
\hline F Value & 3.933 & & & & \\
\hline$R^{2}$ & 0.343 & & & & \\
\hline Adjusted R & 0.256 & & & & \\
\hline
\end{tabular}

\section{Discussion}

Based on the results shown, feedback self-efficacy of feedback orientation is the most significant towards job performance among academicians with the value of regression coefficient for self-efficacy $(r=0.369, p=0.015)$ and correlation value $r=0.388, p=0.000$. It indicates that there is a relationship between self-efficacy and job performance among academicians. For the hypotheses in this study, $\mathrm{H}_{1}$ will be accepted whilst $\mathrm{H}_{0}$ will be rejected. This finding is supported by Omar et al. (2016) in which the study entails that self-efficacy contributes towards job performance among employees. Self-efficacy is important to increase motivation hence improve performance of individual (Bandura and Locke,2003). Tims, Bakker, \& Derks (2014) also state that self-efficacy may enhance performance because a person who believes him or herself as highly efficacious will portray their efforts to handle the job given with longer time in comparison to others.

The next objective is to identify whether there is a relationship between feedback environment of favorable feedback and job performance. From the data gathered favorable feedback has a significant positive relationship and weak association with the job performance among academicians with regression coefficient value of $r=0.294, p=0.003$ and correlation value of $r=0.437, p=0.000$. Therefore, it reveals that favorable feedback has a positive effect towards job performance among academicians. For the hypothesis in this study $\mathrm{H}_{1}$ will be accepted and $\mathrm{H}_{0}$ rejected.

Other variables indicate no relationship and not significant utility $(r=0.128, p=0.199)$, accountability $(r=-0.110, p=0.376)$, social awareness $(r=-0.130, p=0.686)$, source credibility $(r=0.037, p=0.707)$, feedback quality $(r=-0.128, p=0.267)$, feedback delivery $(r=-0.009$, $p=0.909)$, unfavorable feedback $(r=-0.046, p=0.569)$, source availability $(r=0.360, p=0.266)$ and feedback seeking $(r=-0.179, p=0.185)$. 


\section{Recommendations and Conclusion}

In conclusion, understanding performance feedback is crucial for human resource management specifically in performance management. This correlational study provides an understanding of factors influencing job performance. It is known that performance feedback may encourage the growth of career and motivation among academicians. Furthermore, it will enhance employees' productivity hence improving organization performance. Human resource management team may also improve self-efficacy among employees by continuously providing either positive or negative performance feedback to employees as a mean to develop and boost employees' performance. Forming a supportive team to share knowledge using coaching and mentoring system can also be an effective way to increase selfefficacy. Guidance by senior employees through knowledge and experience sharing sessions can also improve job performance among employees. Next, in relation to favorable feedback, it is recommended that managers must praise employees who perform well in their jobs to encourage them to perform better in future. Moreover, praises and recognition by managers can built relational return of loyalty, improve productivity, and generate creative ideas from employees. Employees who received recognition will feel appreciated and thus improve their self-worth. This in return will motivate them to perform better at their job.

Future research can be conducted using the same research study in other similar organizations which will enable researchers to identify factors that are associated with job performance. Thus, allowing the results of this study to be generalized in the specific industry. It is also recommended that future research about the factors influencing job performance should include more variables to achieve accurate results of findings. Having more variables will enhance the contribution to performance management. As the conclusion, this study found that there were positive and significant relationships between feedback self-efficacy of feedback orientation and job performance. To summarize, the higher an employee's selfefficacy or favorable feedback is, the higher his or her job performance will be achieved in an organization.

\section{Acknowledgement}

This research was funded by Universiti Teknologi MARA, file no 600-IRMI 5/3/DDF (FPP) (022/2019).

\section{References}

Baker, A., Perreault, D., Reid, A., \& Blanchard, C. M. (2013). Feedback in organizations: Feedback is good, feedback-friendly culture is better. Canadian Psychology, 54, 260-268.

Dahling, J. J., Chau, S. L., \& O'Malley, A. L. (2012). Correlates and consequences of feedback orientation in organizations. Journal of Management, 38(2), 531-546.

Dahling, J. J., \& O’Malley, A. L. (2011). Supportive feedback environments can mend broken performance management systems. Industrial and Organizational Psychology, 4, 201-203.

Feys, M., Anseel, F., \& Wille, B. (2011). Improving feedback reports: The role of procedural information and information specificity. Academy of Management Learning \& Education, 10(4), 661-681. 
Gabriel, A. S., Frantz, N. B., Levy, P. E., \& Hilliard, A. W. (2014). The supervisor feedback environment is empowering, but not all the time: Feedback orientation as a critical moderator. Journal of Occupational and Organizational Psychology, 87(3), 487-506.

Gregory, J. B., \& Levy, P. E. (2012). Employee feedback orientation: Implications for effectivecoaching relationships. Coaching: An International Journal of Theory, Research and Practice, 5(2), 86-99.

Gupta, A. K., Vijay, G., \& Malhotra, A. (1999). Feedback-seeking behavior within multinational corporations. Strategic Management Journal, 20, 205-222.

Guo, Y., Liao, J., Liao, S., \& Zhang, Y. (2014). The mediating role of intrinsic motivation on the relationship between developmental feedback and employee job performance. Social Behavior and Personality, 42(5), 731-741.

Kahmann, K., \& Mulder, R. H. (2006). The impact of feedback culture on individual use of feedback. International conference on Human Resource Development: Addressing the value, Tilburg.

Kaymaz, K. (2011). Performance feedback: Individual based reflections and the effect on motivation. Business and Economics Research Journal, 2(4), 115-134.

Kuo, T., Li-An, H., Ya-Jung, W., \& Chien-Ting, L. (2010). The factors influencing employees' attitudes in high-tech environment. Industrial Management \& Data Systems, 110(7), 1054-1072.

Larson, J. R. (1989). The dynamic interplay between employees' feedback-seeking strategies and supervisors' deliver of performance feedback. Academy of Management Review, 14(3),408-422.

Levy, P. E., \& Linderbaum, B. A. (2013). The development and validation of the Feedback Orientation Scale (FOS). Journal of Management 36(6), 1372-1402.

Linderbaum, B. A., \& Levy, P. E. (2010). The development and validation of the feedback orientation scale (FOS). Journal of Management, 36(6), 1372-1405.

Mosca, J. B., Fazzari, A., \& Buzza, J. (2010). Coaching to win: A systematic approach to achieving productivity through coaching. Journal of Business \& Economics Research, 8(5), 115.

Mulder, R. H. (2013). Exploring feedback incidents, their characteristics and the informal learning activities that emanate from them. European Journal of Training and Development, 37(1), 49-71.

Mulder, R. H., \& Ellinger, A. D. (2013). Perceptions of quality of feedback in organizations. Characteristics, determinants, outcomes of feedback, and possibilities for improvement: Introduction to a special issue. European Journal of Training and Development, 37(1), 4-23.

Romero, J. L. (2012). Feedback at work: Create a powerful team through multi-directional feedback. Healthcare Registration (September issue), 7-8.

Silverman, S. B., Pogson, C. E., \& Cober, A. B. (2005). When employees at work don't get it: Amodel for enhancing individual employee change in response to performance feedback. Academy of Management Executive, 19(2), 135-147.

Smither, J. W., London, M., \& Reilly, R. R. (2005). Does performance improve following multisource feedback \& $A$ theoretical model, meta-analysis, and review of empirical findings. Personnel Psychology, 58, 33-66.

Van der Rijt, J., van de Wiel, M. J., Van den Bossche, P., Segers, M. R., \& Gijselaers, W. H. (2012). Contextual antecedents of informal feedback in the workplace. Human Resource Development Quarterly, 23(2), 233-257. 
Van der Rijt, J., Van den Bossche, P., \& Segers, M. S. R. (2013). Understanding informal feedback seeking in the workplace. European Journal of Training and Development, 37(1), 72-85. 